\title{
Resource allocation in Copaifera langsdorffii (Fabaceae): how supra-annual fruiting affects plant traits and herbivory?
}

\author{
Fernanda Vieira da Costa $^{1}$, Antônio César Medeiros de Queiroz ${ }^{2}$, Maria Luiza Bicalho Maia ${ }^{3}$, \\ Ronaldo Reis Júnior ${ }^{4} \&$ Marcílio Fagundes ${ }^{4}$ \\ 1. Laboratório de Ecologia de Insetos, Instituto de Ciências Biológicas, Universidade Federal de Minas Gerais, Av. \\ Antonio Carlos 6627, Belo Horizonte, Minas Gerais, 31270-901, Brazil; fecostabio@gmail.com \\ 2. Departamento de Biologia, Universidade Federal de Lavras S/N, Lavras, Minas Gerais, 37200-000, Brazil; queiro- \\ zacm@gmail.com \\ 3. Departamento de Biologia Geral, Universidade Federal de Viçosa S/N, Viçosa, Minas Gerais, 36570-000, Brazil; \\ m.bmaiabio@gmail.com \\ 4. Departamento de Biologia Geral, Universidade Estadual de Montes Claros S/N, Montes Claros, Minas Gerais, 39400 - \\ 000,Brazil; ronaldo.reis@unimontes.br,marcilio.fagundes@gmail.com
}

\author{
Received 13-IV-2015. C Corrected 07-X-2015. Accepted 04-XI-2015.
}

\begin{abstract}
Plants have limited resources to invest in reproduction, vegetative growth and defense against herbivorous. Trade-off in resources allocation promotes changes in plant traits that may affect higher trophic levels. In this study, we evaluated the trade-off effect between years of high and low fruiting on the investment of resources for growth and defense, and their indirect effects on herbivory in Copaifera langsdorffii. Our questions were: (i) does the resource investment on reproduction causes a depletion in vegetative growth as predicted by the Carbon/Nutrient Balance hypothesis $(\mathrm{CNBH})$, resulting in more availability of resources to be allocated for defense?, (ii) does the variation in resource allocation for growth and defense between years of high and low fruiting leads to indirect changes in herbivory? Thirty-five trees located in a Cerrado area were monitored during 2008 (year of high fruiting) and 2009 (year of no fruiting) to evaluate the differential investment in vegetative traits (biomass, growth and number of ramifications), plant defense (tannin concentration and plant hypersensitivity) and herbivory (galling attack and folivory). According to our first question, we observed that in the fruiting year, woody biomass negatively affected tannin concentration, indicating that fruit production restricted the resources that could be invested both in growth as in defense. In the same way, we observed an inter-annual variation in herbivorous attack, and found that plants with higher leaf biomass and tannin concentration, experienced higher galling attack and hypersensitive reaction, regardless years. These findings suggested that plants' resistance to herbivory is a good proxy of plant defense and an effective defense strategy for C. langsdorffii, besides the evidence of indirect responses of the third trophic level, as postulated by the second question. In summary, the supra-annual fruiting pattern promoted several changes on plant development, demonstrating the importance of evaluating different plant traits when characterizing the vegetative investment. As expected by theory, the trade-off in resource allocation favored changes in defense compounds production and patterns of herbivory. The understanding of this important element of insect-plant interactions will be fundamental to decipher coevolutionary life histories and interactions between plant species reproduction and herbivory. Besides that, only through long-term studies we will be able to build models and develop more accurate forecasts about the factors that trigger the bottom-up effect on herbivory performance, as well the top-down effect of herbivores on plant trait evolution. Rev. Biol. Trop. 64 (2): 507-520. Epub 2016 June 01.
\end{abstract}

Key words: galling insects, mass fruiting, phenology, plant defenses, trade-off.

Plants have limited resources to invest in reproduction, growth and defense against herbivorous insects or pathogens (Bazzaz, Chiariello, Coley, \& Pitelka, 1987; Herms \&
Mattson, 1992; Stamp, 2003). Usually, the demand of resources for those three processes cannot be simultaneously met, resulting in a trade-off in the resource allocation among 
different physiological routes (Herms \& Mattson, 1992; Obeso, 2002; Weiner, Campbell, Pino, \& Echarte, 2009). The differential investment in resources produces changes in plant traits (e.g., architecture, growth and concentration of defense compounds), which may extend their effects to higher trophic levels (Bazzaz et al., 1987; Obeso, 2002; Stamp, 2003; Buckley \& Avila-Sakar, 2013). Trade-offs in resource allocation are especially important in plants with supra-annual fruiting, since the investment in fruit production is high and limited into short periods (Janzen, 1971; Kelly, 1994; Newstrom, Frankie, \& Baker, 1994). In fact, periods of intense fruiting are frequently associated with reduction or suspension of different plant physiological processes as result of internal nutrient rearrangement (Isagi, Sugimura, Sumida, \& Ito, 1997; Obeso, 2002).

Trade-offs between reproduction and growth is a common phenomenon in higher plants (Obeso, 2002). During fruits development, plants may reduce or even stop their vegetative growth because fruits are stronger nutrient drains (Abrahamson \& Caswell, 1982; Larcher, 1995). Experimental studies with different species demonstrated that deletion of reproductive structures increase plant vegetative growth (Obeso, 2002). Additionally, the differential investment in growth and reproduction may affect the production of defense compounds (Jing \& Coley, 1990; Obeso, 2002) and rather affects herbivores attack (Buckley \& Avila-Sakar, 2013).

According to the Carbon/Nutrient Balance hypothesis $(\mathrm{CNBH})$ the disparity of resources investment in reproduction or vegetative growth may affect the phenolic content in leaf tissues (Bryant et al., 1983; Herms \& Mattson, 1992). Under favorable conditions (e.g. no fruiting year), plants preferentially allocate carbon (C) for growth, reducing the concentration of carbon-based defense compounds. Alternatively, when the availability of nutrients (N) is restricted (e.g. during a mass fruiting event), the excess of $\mathrm{C}$ normally is displaced to the synthesis of carbon-based compounds (Bryant et al., 1983; Herms \& Mattson, 1992;
Stamp, 2003). Among the carbon-based chemical defenses, tannins are among the most efficient ones against chewing herbivores (Coley, 1986). Tannins are dose-dependent compounds (Feeny, 1976; Coley, 1986), acting in the precipitation of proteins in the intestinal tract of herbivores (Coley \& Barone, 1996).

The performance of herbivores on host plant may vary accordingly with tissues qualities (Dyer et al., 2004; Neves et al., 2010), likewise the outcomes of these interactions when herbivores are under dose-dependent defense compounds' effects (e.g., tannins) (Roslin \& Salminen, 2008). Usually, generalist-chewing insects are directly affected by mechanisms of quantitative chemical defenses (Feeny, 1976; Ribeiro, Braga, Silva, \& Fernandes, 1999; Neves et al., 2010). Although galling insects are specialist herbivores that are minimally affected by defensive compounds, because they are able to manipulate them in its favor (Hartley, 1998); they are sensitive to induced defenses. In fact, some studies have demonstrated the importance of hypersensitivity reactions (HRs) in regulating the populations of galling insects (Fernandes, 1990; Fernandes \& Negreiros, 2001). HR is a type of local induced defense also known as plant resistance, which occurs in the area adjacent to the insect oviposition. The mechanism of HR action by plants includes a morphological and histological change that leads to tissue necrosis after the galling insect attack, interrupting its development (Barbosa \& Fernandes, 2014).

Perennial species that experience supraannual fruiting are good models for testing hypothesis regarding trade-offs in resource allocation (Norton \& Kelly, 1988; Kelly \& Sork, 2002). This fruiting pattern is characterized by the intense fruit production followed by years of little or no fruiting (Kelly, 1994; Isagi et al., 1997; Pedroni, Sanchez \& Santos, 2002). Thus, it is expected that inter-annual variations in fruit production may affect vegetative growth and production of defense compounds, with effects on higher trophic levels (Bazzaz et al., 1987; Obeso, 2002; Stamp, 2003). 
In this study we evaluated the trade-off between years of high and low fruiting in the investment of resources on growth and defense, and their indirect effects on herbivory in Copaifera langsdorffii Desf. (Fabaceae: Caesalpinioideae). Our research questions were: (i) does the resource investment on reproduction causes a depletion in vegetative growth as predicted by $\mathrm{CNBH}$, resulting in more availability of resources to be allocated for defense?, (ii) does the variation in resource allocation for growth and defense between years of high and low fruiting leads to indirect changes in herbivory? We predicted that plants during mass fruiting year should decrease vegetative traits production, benefit defense allocation, and consequently would experience lower herbivory due to folivory and galling insects.

\section{MATERIALS AND METHODS}

Study system: Copaifera langsdorffii is a perennial tropical tree that reaches up to ten meters height in Cerrado vegetation. Although C. langsdorffii has a pronounced deciduousness in the dry season (July to September) (Pedroni et al., 2002), it is considered a leaf-exchanging tree since leaf flushing occur immediately after leaf falling (Freitas \& Oliveira, 2002). The fruiting is supra-annual, i.e., years of intense fruiting are followed by years of little or no fruit production (Sebbenn et al., 2011; Souza, Sollar, \& Fagundes, 2015). In the study area, this species has already experienced a gap of two following years with no fruiting (Souza et al., 2015). Moreover, C. langsdorffii has the most rich gall herbivorous insect fauna in the Neotropics (Costa, Fagundes, \& Neves, 2010) and high diversity of free-living herbivorous insects (Silva, Jesus, Fagundes, \& Fernandes, 2009).

Study area: The study was conducted in a private reserve inserted in a fragmented Cerrado area in the city of Montes Claros (16 $40^{\prime} 8^{\prime \prime}$ S - 434' $25^{\prime \prime}$ W), Northern of Minas Gerais State, Brazil. The region is inserted in the ecotone between Cerrado and Caatinga domains
(Rizzini, 1997), with semi-arid climate characterized by well-defined dry and rainy seasons. The annual average temperature is $23{ }^{\circ} \mathrm{C}$ with rainfall of approximately $1000 \mathrm{~mm} /$ year, with rains concentrated between November and January (Fagundes et al., 2013a). The soil of the study area is dystrophic with a developed herbaceous subshrub layer, generally affected by fire (Fagundes, et al. 2013b).

Experimental design: In March 2008, 35 C. langsdorffii individuals in initial stage of fruiting were marked. Those individuals were from five to seven meters high and had a well-formed crown. Those plants were monitored monthly during 2008 and 2009 years to determine the presence of flowers and fruits, thereby featuring the occurrence of reproductive stage. All individuals produced fruits in 2008; whereas none of them produced flowers or fruits in 2009 (this pattern was common to the entire population present in the study area). Thereafter, 2008 was considered the reproductive year and 2009 the no-reproductive year.

During the month of May in each studied year (time of vegetative growth and before leaf fall), ten terminal branches were sampled from all marked plants. The branches were collected at different points of the crown in order to minimize possible microclimatic effects on plant growth, defenses or herbivory (Costa et al., 2010). Those branches were approximately $30 \mathrm{~cm}$ long, corresponding to the last plantgrowing season, i.e., from budding until complete leaf expansion and ripening. The branches were taken to the laboratory, where the following traits were measured: number of fruits, fruit biomass, leaf biomass, woody biomass, number of ramifications, vegetative growth, galling richness and abundance, galling attack and success, and number of HR. Further, 30 leaves per tree were randomly sampled to assess the leaf area lost by folivory and tannin concentration in leaf tissues. All these plant's features are described in the following sections.

Reproductive and vegetative investment: The number of fruits was determined by 
counting the fruits present in the ten branches sampled from each plant. All fruits were dried in an oven at $70{ }^{\circ} \mathrm{C}$ for $72 \mathrm{~h}$, and weighed on an electronic precision scale $(0.01 \mathrm{mg} /$ Shimadzu Corp. AUW 220) to reproductive biomass determination. In order to qualify the vegetative investment we took all the leaves present in those branches and weighed to determine leaf biomass. We also assessed the woody biomass, number of ramifications and the vegetative growth in the same branches. The number of ramifications represents the amount of young shoots located in the apical portion of the branch, which can be a proxy of active meristems in a given individual (Espírito-Santo et al., 2007 for details). The vegetative growth of each plant was measured by the average length of the same young shoots located in the apical portion of the branch that corresponds the last plant-growing season.

Herbivorous attack: Galling insect richness and abundance were determined by counting the number of galls present in the same ten branches collected in each plant. We also distinguish leaf galls from branch galls in order to achieve components on different strategies of galling inducing. The external morphology, color, size, and indumentums, of galls were used to characterize and define the morphotypes (Stone \& Schönrogge, 2003). The identification of galling insect morphotypes were according to Costa et al., (2010) and Appendix. Additionally, we determined the number of HR, number of galling insect attacks (leaf galls abundance + HR) and number of successful leaf galls (abundance of leaf galls/attack*100). HR is featured by a clear halo formed by leaf necrosis, which occurs after the attack of galling insect (Fernandes \& Negreiros, 2001). Sometimes, the damage caused by herbivores can be confused with the drop of necrotic spots due to HR. However, the branches of $C$. langsdorffii were collected before leaf senescence, when necrotic area due to HR present circular edges and the central necrotic tissues have not fallen. Moreover, HR marks in C. langsdorffii leaves can be distinguished from folivory since the borders of the halo formed by HR remained after tissues fall. Folivory caused by chewing herbivorous insects was determined in 30 leaves by plant through the percentage of leaf area lost. These leaves were digitalised and their total and removed areas were estimated by the software ImageJ (Rasband, 1997-2014).

Defense investment: Tannin leaf concentration was used as a surrogate of defense investment and was determined through radial diffusion method (Hagerman, 1987). This essay commonly used to quantify condensed and hydrolysable tannins, determines tannin in plant extracts by its reaction with a protein and quantifying the precipitated complex. The astringency (protein-precipitation property) depends on the concentration and on the composition of tannins on plant leaf (Haslam, 1988) thus, astringency should be proportional to tannin concentration and provide a good estimative of defence.

We collected 30 mature leaves from each plant and dried them in an oven at $45{ }^{\circ} \mathrm{C}$ for $72 \mathrm{~h}$. In this procedure, the sample supernatant (50 mg with $1 \mathrm{~mL}$ of $50 \%$ methanol) after centrifugation (11000 rpm for 15 minutes) was applied directly in the diffusion in gel; $20 \mu \mathrm{L}$ of the extract was added to a Petri dish containing a mixture of agar and protein (bovine albumin). The extract was placed in uniform circles 2.8 $\mathrm{mm}$ in diameter and $1.5 \mathrm{~cm}$ equidistant perforated in the agarose. The dishes were sealed with parafilm and incubated at $30{ }^{\circ} \mathrm{C}$ for $96 \mathrm{~h}$. The tannin extract after the reaction with the albumin forms a visible precipitate in which the square diameter is proportional to tannin concentration in the sample. Tannic acid was used for the construction of a standard curve (for more details, see Hagerman, 1987).

We used linear mixed effect models (LME) to answer our questions (Crawley, 2007). The repetitive data sampling in the same 35 plants in subsequent years leads to temporal autocorrelation of samples that violates the assumption of sample independence. To overcome this problem, the data were grouped by plant and the variances of errors were calculated for each 
different group. In this way, the response was not the individual measure but the sequence of measures at one individual, but the resulting groups from the clustered data by plant were treated as a random effect (study year/ plant). The appropriate minimum models were obtained with the removal of non-significant variables $(P>0.05)$ of complete models, and afterwards waste analysis was used to check the suitability of models and error distributions (Crawley, 2007). All analysis were performed with the software R (R Development Core Team, 2008).

To answer the first question, if the investment in fruiting causes a depletion on vegetative growth and promote total protein precipitation capacity of the leaf, we used the vegetative traits (vegetative biomass, leaf biomass, wood biomass, number of ramifications and growth) and tannin concentration as response variables and the study year as the explanatory variable. Additionally, we built a model to see if there was a trade-off between growth and defense as proposed by $\mathrm{CNBH}$ hypothesis. In this case, the response variable was tannin concentration and the explanatory variables were leaf biomass, wood biomass and the interaction among those variables.

To answer the second question, if the variation in resource allocation between years of high and low fruiting leads to indirect changes on herbivory, we adjusted complete models in which the response variables were those related with herbivory (total gall abundance, total gall richness, leaf galls abundance, leaf galls richness, stalk galls abundance, stalk galls richness, number of HR, number of attacks, galling successful and leaf area lost), and the explanatory variables were the study years, leaf biomass, wood biomass, tannin concentration and the interaction among those variables.

\section{RESULTS}

Variation in resource allocation between years: The population of $C$. langsdorffii studied exhibited a strong variation in fruit production, with intense fruiting in 2008 , followed by a lack of fruiting in the subsequent year. In fact, during 2008 year, we found approximately $13.3 \pm 5.8$ (average \pm SE) fruits per branch, corresponding to $139.5 \pm 53.8 \mathrm{~g}$ (average $\pm \mathrm{SE}$ ) of fruit biomass by sampled branch. This reproductive biomass corresponds to over half (57.6 $\%$ ) of the total vegetative biomass produced per plant in 2008.

The investment on total vegetative biomass (leaves + woody) did not change between years of fruiting (Table 1). However, some vegetative traits varied between years: leaf biomass and the number of ramifications were $28.9 \%$ and $30.5 \%$ lower in the reproductive year, respectively (Fig. 1A, Fig. 1C; Table 1); while the woody biomass and vegetative growth were higher in the reproductive year $(23.3 \%$ and $40.6 \%$ respectively) (Fig. 2B, Fig. 2D).

Tannin concentration was approximately $157 \%$ higher in fruiting year (Fig. 1E). Hence, tannin concentration was influenced by an interaction among studied years and woody biomass (Fig. 2; Table 1). During the year of high fruiting, woody biomass negatively affected tannin concentration. Conversely, the woody biomass positively affected tannin concentration in the no-reproductive year, time of low tannin investment.

Resource allocation and effects on herbivory: In the reproductive year, we sampled 952 galls distributed in 18 morphotypes (Appendix). In the no-reproductive year, we found almost the double, 1772 galling, belonging to 19 morphotypes (Appendix). Galls richness and abundance were higher in the noreproductive year $(34.3 \%$ and $85.7 \%$, respectively) (Fig. 3A, Fig. 3B; Table 1). Similarly, leaf galls abundance, stalk galls abundance, number of HR and number of attacks were higher in the no-reproductive year (respectively $115.1 \%, 53.6 \%, 46.0 \%$ and $47.6 \%$ ) (Fig. 3 C, Fig. 3D, Fig. 3E, Fig. 3F; Table 1). However, successful leaf galls was not different among studied periods; and leaf area lost was approximately $115.3 \%$ higher in the reproductive year (Fig. 3G; Table 1). 
TABLE 1

Suitable minimum models used to evaluate the inter-annual variations in resource allocation and their effects on herbivory in Copaifera langsdorffii $(\mathrm{n}=35)$

\begin{tabular}{|c|c|c|c|c|}
\hline Response variables & Explanatory variables & $\mathrm{df}^{\dagger}$ & $\mathrm{F}$ & P-value \\
\hline Vegetative biomass & Study year & 34 & 0.004 & 0.952 \\
\hline Leaf biomass & Study year & 34 & 13.795 & $<0.001$ \\
\hline Wood biomass & Study year & 34 & 17.502 & $<0.001$ \\
\hline Number of branches & Study year & 34 & 25.984 & $<0.001$ \\
\hline Growth of branches & Study year & 34 & 11.852 & 0.001 \\
\hline \multirow[t]{3}{*}{ Tannin } & Study year & 32 & 62.341 & $<0.001$ \\
\hline & Wood biomass & 32 & 2.490 & 0.124 \\
\hline & Study year $\mathrm{x}$ wood biomass & 32 & 5.148 & 0.030 \\
\hline Total abundance of galls & Study year & 34 & 13.507 & $<0.001$ \\
\hline Total richness of galls & Study year & 34 & 4.626 & 0.039 \\
\hline Abundance of leaf galls & Study year & 34 & 8.895 & 0.005 \\
\hline Richness of leaf galls & Study year & 34 & 3.023 & 0.091 \\
\hline Abundance of stalk galls & Study year & 34 & 4.310 & 0.049 \\
\hline Richness of stalk galls & Study year & 34 & 0.760 & 0.389 \\
\hline \multirow[t]{4}{*}{ Number of HR } & Study year & 31 & 8.131 & 0.008 \\
\hline & Leaf biomass & 31 & 3.701 & 0.081 \\
\hline & Tannin & 31 & 1.895 & 0.178 \\
\hline & Leaf biomass $\mathrm{x}$ tannin & 31 & 6.241 & 0.015 \\
\hline \multirow[t]{4}{*}{ Number of attack } & Study year & 31 & 9.228 & 0.005 \\
\hline & Leaf biomass & 31 & 3.699 & 0.064 \\
\hline & Tannin & 31 & 2.029 & 0.164 \\
\hline & Leaf biomass $\mathrm{x}$ tannin & 31 & 6.240 & 0.018 \\
\hline \multirow[t]{3}{*}{ Survival of galls } & Study year & 32 & 1.960 & 0.171 \\
\hline & Leaf biomass & 32 & 0.127 & 0.724 \\
\hline & Study year x leaf biomass & 32 & 5.528 & 0.025 \\
\hline \multirow[t]{3}{*}{ Leaf area lost } & Study year & 32 & 34.459 & $<0.001$ \\
\hline & Leaf biomass & 32 & 10.815 & 0.002 \\
\hline & Study year x leaf biomass & 32 & 5.744 & 0.023 \\
\hline
\end{tabular}

$\dagger \mathrm{df}=$ degrees of freedom from residue.

Galling richness and abundance were not directly associated with vegetative biomass or tannin concentration. However, in the two years, the number of HR and number of galling attack were positively affected by the interaction among leaf biomass and tannin concentration (Fig. 4; Table 1). Thus, plants that experienced higher leaf biomass and defense had more attempts of attack by herbivorous and consequently, higher resistance.

Successful leaf galls and leaf area lost by folivory were affected by the interaction between study year and leaf biomass (Fig. 5;
Table 1). Leaf biomass negatively affected successful leaf galls in the reproductive year, while a positive effect was observed in the no-reproductive (Fig. 5A). Finally, leaf biomass negatively affected folivory in both census, but it was stronger during reproductive year (Fig. 5B).

\section{DISCUSSION}

Our results show high inter-annual variation in fruiting. This pattern of supra-annual reproduction characterized by synchronic and 

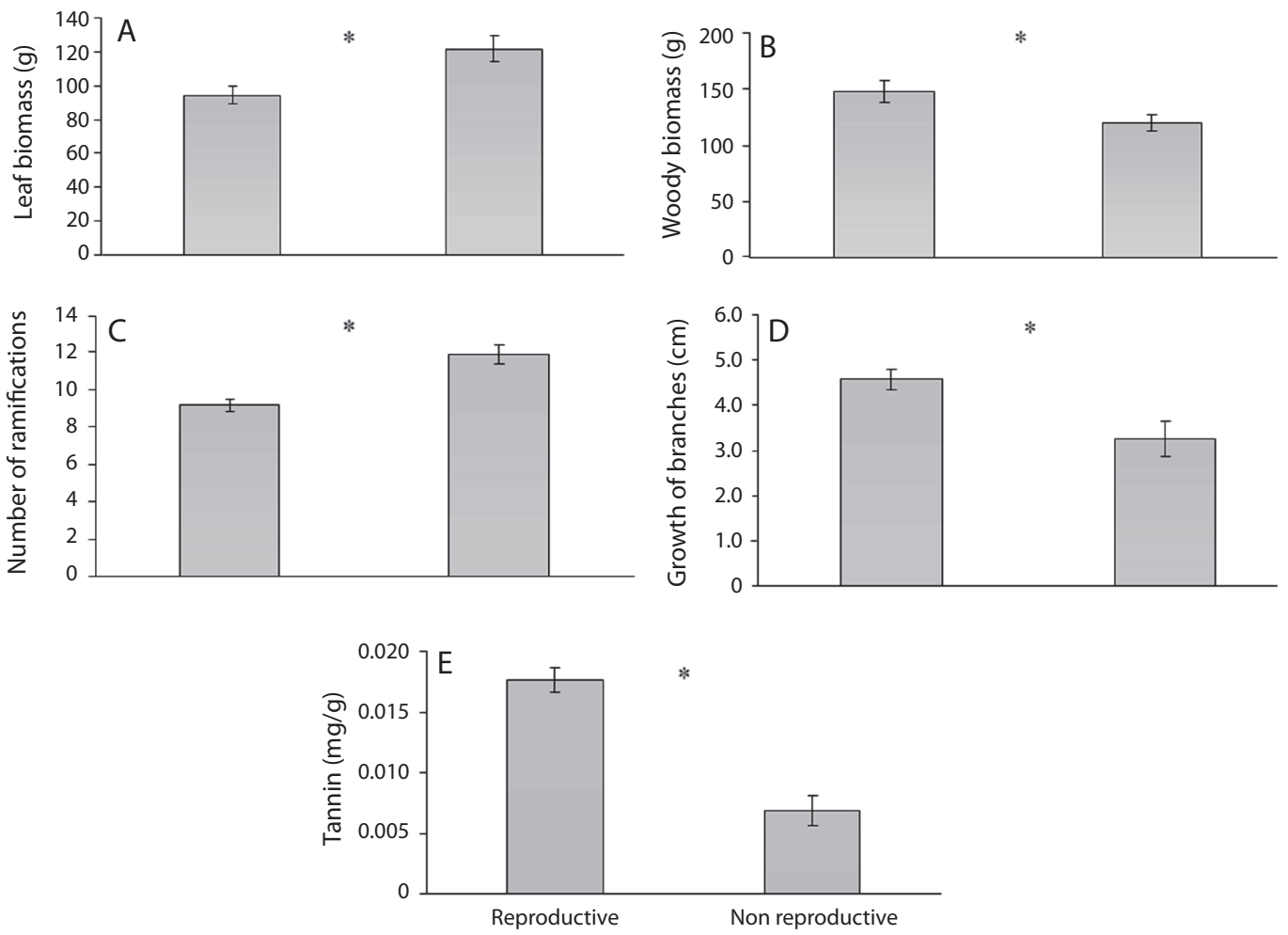

Fig. 1. Leaf biomass (A), wood biomass (B), number of ramifications (C), growth of branches (D) and tannin concentration (E) produced by Copaifera langsdorffii in the reproductive and non-reproductive years $(n=35$; average per plant \pm SE; Table 1. * represents significant differences.

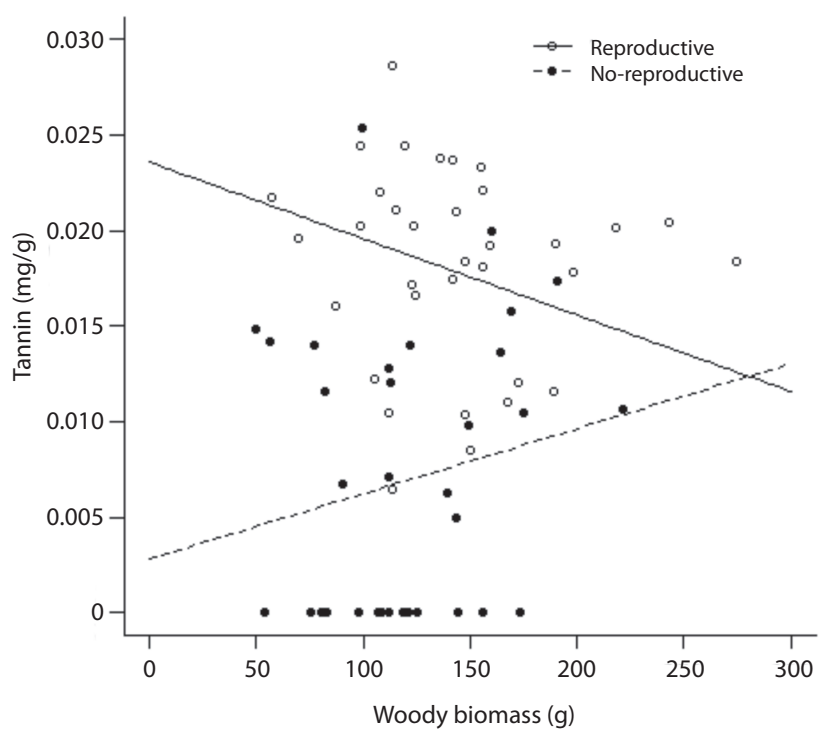

Fig. 2. Inter-annual effects of woody biomass on tannin concentration in Copaifera langsdorffii. Curves were built with parameters obtained from the minimum suitable model (LME) $(n=35$; Table 1$)$. 

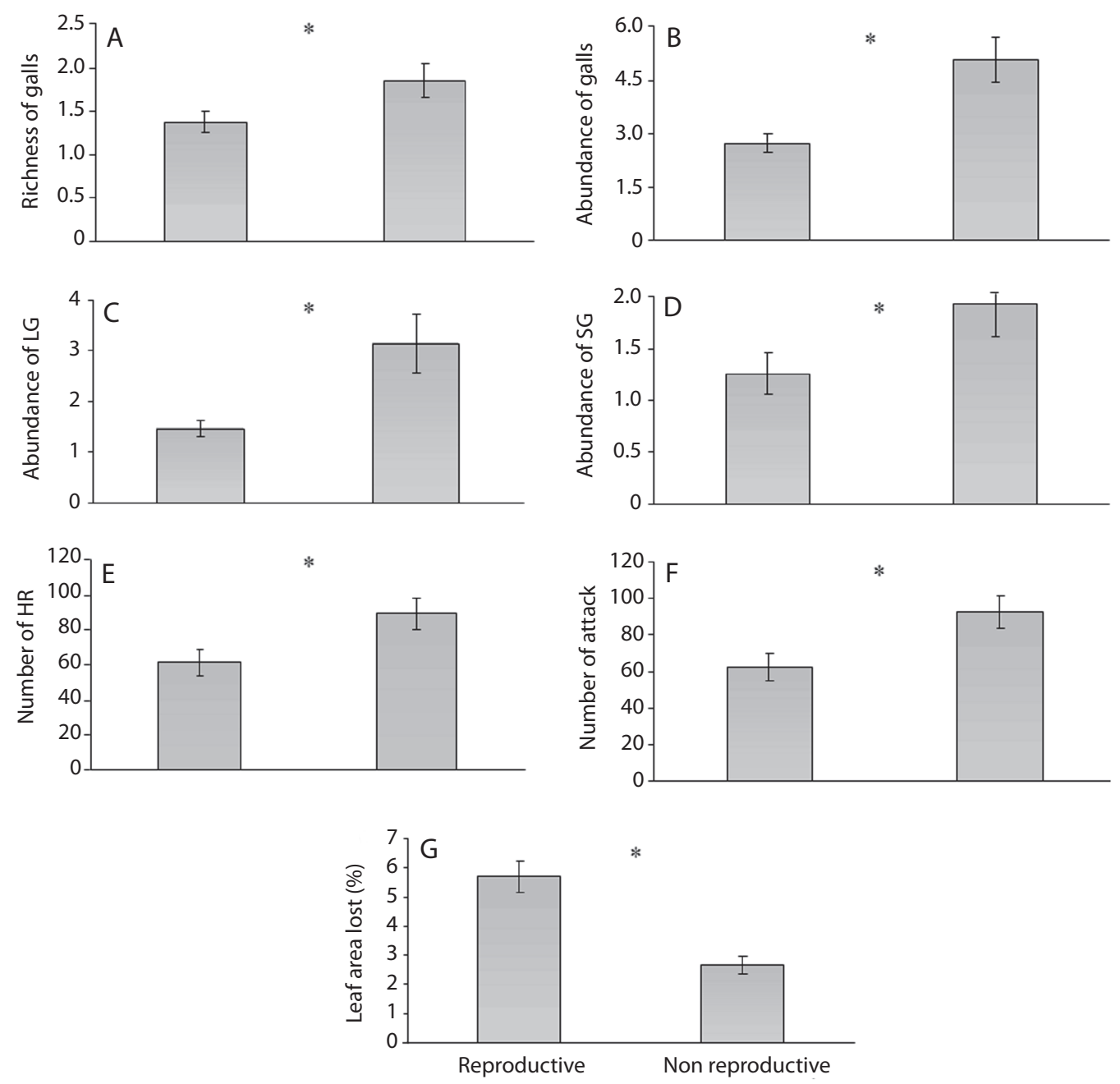

Fig. 3. Galls richness (A), galls abundance (B), leaf galls abundance (C), stalk galls abundance (D), number of HR (E), number of attacks (F) and leaf area lost by folivory (G) present in Copaifera langsdorffii in the reproductive and nonreproductive years $\left(n=35\right.$; average per plant \pm SE; Table $1 .{ }^{*}$ represents significant differences.

intermittent fruiting inside one population appears to be common for the Copaifera genus (Leite \& Salomão, 1992; Dias \& Oliveira-Filho, 1996; Pedroni et al., 2002). Several studies have been conducted for the understanding of internal resource allocation necessary to keep the costs of supra-annual reproductive cycles (e.g., Satake \& Iwasa, 2000; Monks \& Kelly, 2006; Souza et al., 2015). However, no study has attempted to explain the ecological role of supra-annual fruiting of tropical species on the investment of resources in the individual level, even extrapolating their effects to another trophic level.

It is difficult to evaluate and interpret the effects of supra-annual fruiting in the development of perennial plants (Buckley \& AvilaSakar, 2013). First, the reproductive allocation may be reflected in the vegetative traits of subsequent years (Ishihara \& Kikuzawa, 2009; Sandvik \& Eide, 2009). Second, plants can compensate the costs of reproduction through 


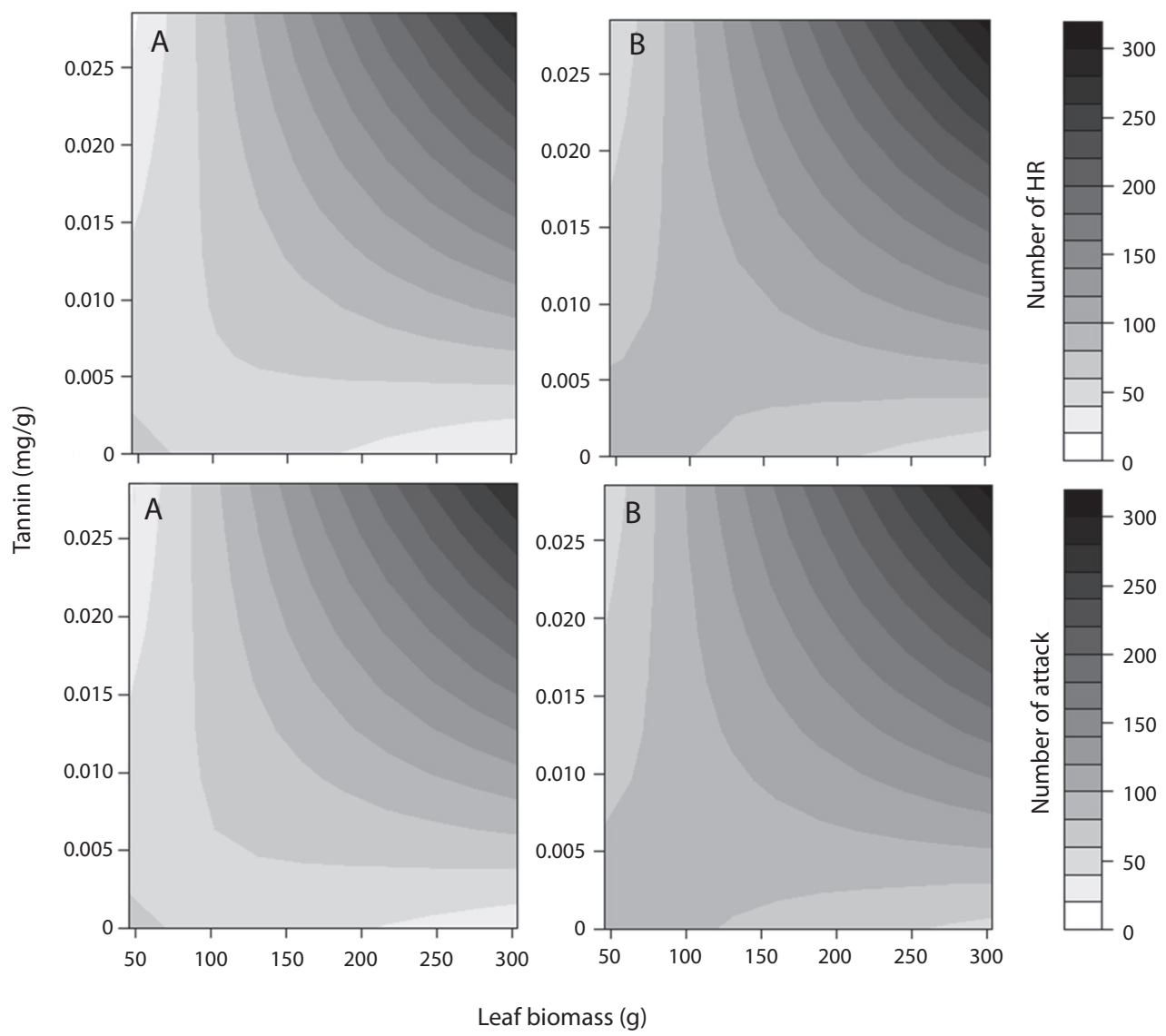

Fig. 4. Effect of tannin concentration and leaf biomass on the number of resistance (HR) and galling insects attack on Copaifera langsdorffii $(\mathrm{A}=$ reproductive year, $\mathrm{B}=$ no-reproductive year; $\mathrm{n}=35$; Table 1$)$.

reserves stored in years before reproduction or through an increase in resources absorption (Sandvik \& Eide, 2009). Finally, disentangling all metabolic and physiologic routes of plants is still limited, making difficult the interpretation of results (Baldwin et al., 1998; Mole, 1994). Although the high inter-annual variation in fruiting, C. langsdorffii invested similarly in total vegetative biomass production between the two years. However, we found lower number of ramifications and leaf biomass in the reproductive year, opposed by the higher growth and woody biomass in the same period. These results illustrate that intermittent fruiting did not affect the investment of energy for vegetative traits as a whole, but altered plant priorities and development. This scenario indicates that plant resource allocation is complex and may be reflected in different vegetative traits.

Leaf tannin concentration and branches growth was higher in the reproductive year. In fact, these results match our prediction as we observed lower investment in leaf biomass and number of ramifications, against higher investment in defense and vegetative growth during fruiting. Chemical defense was also affected by wood biomass in different ways according to year. In the reproductive year, plants that experienced higher wood biomass probably invested less in tannin production, as predicted by CNBH (Herms \& Mattson, 1992). It is 


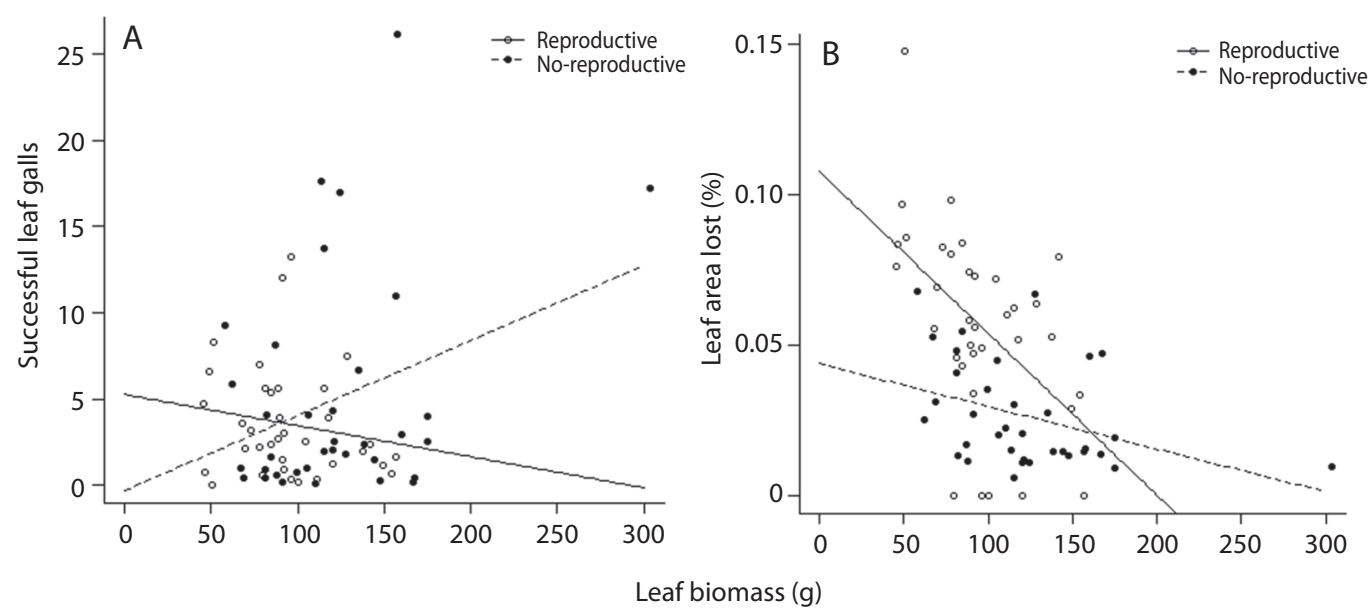

Fig. 5. Inter-annual effect of leaf biomass on leaf galling successful (A) and leaf area lost due to chewing herbivores (B) in Copaifera langsdorffii. Curves were built with parameters obtained from the minimum suitable model (LME) $(n=35$; Table 1).

likely that fruit production in 2008 restricted the resources, which could be invested both in growth and defense, leading to a conflicting demand between those two physiological processes. Alternatively, in the no-reproductive year, it seems that the resources were enough to be invested in growth and defense, justifying the positive relationship between wood biomass and tannin concentration (Baldwin et al., 1998; Haring et al., 2008; Imaji \& Seiwa, 2010).

When we look into herbivory, we observed a great richness of galling insects (19 morphotypes) that corroborate the previous pattern already described for Copaifera langsdorffii - a super-host of galling insects (Costa et al., 2010). The high environmental stress and the low pressure exerted by natural enemies have been used to explain the high diversity of galling insects in plants from Cerrado (Fernandes $\&$ Price, 1992). The low levels of folivory found in this study (approximately $6.0 \%$ in 2008 and $3.0 \%$ in 2009) were similar to other studies conducted in Cerrado areas (Fowler \& Duarte, 1991: $4.6 \%$ to $9.3 \%$; Marquis et al., 2001: $5.0 \%$ to $6.8 \%$; Neves et al., 2010: 2.0 $\%)$. The low availability of nutrients in Cerrado soils and the elevated rate of leaf sclerophylly have been used to explain the low leaf herbivory caused by chewing insects (Neves et al., 2010).

Besides the inter-annual variation in herbivorous attack, plants with higher leaf biomass and tannin concentration experienced higher galling attack and HR, regardless years. Plant hypersensitivity to herbivory can be used as a proxy of plant defense and seems to be an effective defense strategy (Buckley \& AvilaSakar, 2013). As follows, plants with higher tannin concentration should be more resistant to herbivorous and pathogenic attacks, supporting the high physical resistance observed in those plants (Westphal et al., 1981; Hartley, 1998). Moreover, the positive relation linking leaf biomass and galling attack is coherent since leaves are essential resources for galling oviposition (Faria \& Fernandes, 2001). However, almost no study reports the role of HR in the dynamics of galling insect populations and the mechanisms behind its action (but see Fernandes et al., 2012).

Successful leaf galls were negatively affected by leaf biomass in the reproductive year, whereas in the no-reproductive year this relationship was positive. We hypothesize that competition is a possible cause to explain this pattern, considering the great 
occurrence of galling insect on C. langsdorffii and their potential top-down pressures (Hess et al., 1996). Additionally, leaf biomass was smaller and tannin production was higher during reproduction, indicating a restricted availability of suitable resources for leaf galling insects that responded with lower abundance and survival in this period. On the contrary, leaf biomass was greater in no-reproductive year, resulting in lower competition for food, and consequently, higher success in plants with greater resources availability. Although $C$. langsdorffii experienced low levels of folivory in both periods, it was higher in fruiting year and negatively responds to leaf biomass effect. Therefore, plants showing higher leaf biomass had a smaller leaf area removed by folivory, probably due to the higher dilution of damages caused by chewing insects when resources are more abundant.

This study confirms that Copaifera langsdorffii has a supra-annual fruiting pattern. This reproductive strategy promoted several effects on plant development, indicating the importance of evaluating different plants traits to characterize the vegetative investment of a species. We highlight that other physiological process, as the assessment of reserves stored by plants during phenology phases, should be investigated to clarify the trade-offs between reproduction, growth and defense. The supra-annual fruiting also affected production of defense compounds and the herbivorous fauna associated with $C$. langsdorffii. Studies that investigate the differential investment in defenses and their role on higher trophic levels in supra-annual plants are still rare to find. The understanding of this important element of insect-plant interactions will be fundamental to decipher coevolutionary life histories and the role of herbivory in plants reproduction, and vice versa. Besides that, only through longterm studies we will be able to build models and develop more accurate forecasts about the factors that trigger the bottom-up effect on herbivory performance, as well the top-down effect of herbivores on plant trait evolution.

\section{ACKNOWLEDGMENTS}

We thank Camila R. O. Leal for helping in field and laboratory work. Fernanda V. Costa is grateful for the scholarship provided by Coordenação de Aperfeiçoamento de Pessoal de Nível Superior (Capes), and Ronaldo Reis-Júnior and Marcilio Fagundes are grateful for the scholarship from Fundação de Amparo a Pesquisa de Minas Gerais (FAPEMIG). This study was funded by FAPEMIG (APQ-01231-09).

\section{RESUMEN}

Las plantas tienen recursos limitados para invertir en reproducción, crecimiento vegetativo y defensa contra herbívoros. El cambio en la distribución de recursos promueve variaciones en rasgos vegetales, que pueden afectar los niveles tróficos superiores. Durante dos años consecutivos de alta y baja inversión reproductiva se evaluó el cambio de recursos entre crecimiento vegetativo y defensa, y su efecto indirecto sobre la herbivoría en Copaifera langsdorffii. Nos preguntamos: i) ¿La inversión de recursos para la reproducción causa reducción del crecimiento vegetativo, como predice la hipótesis de equilibrio carbono/nutrientes, haciendo posible gastar más recursos en defensa? ii) ¿La variación en distribución de recursos para crecimiento y defensa entre años de alta y baja fructificación modifica indirectamente la herbivoría? Se monitorearon treinta y cinco árboles durante 2008 (gran fructificación) y 2009 ( $\sin$ fructificación) en un área de vegetación de cerrado (Brasil), para evaluar la inversión diferencial en rasgos vegetativos (biomasa, crecimiento y No. de ramificaciones), defensa (concentración de taninos e hipersensibilidad vegetal) y herbivoría. De acuerdo a nuestra primera pregunta, se observó que en el año de fructificación la biomasa leñosa afectó negativamente la concentración de taninos, indicando que la producción de frutos redujo los recursos que podían invertirse en crecimiento y defensa. Además, la resistencia de las plantas y el ataque de agallas fueron influidos positivamente por la concentración de taninos y la biomasa foliar, lo que sugiere que la resistencia de los árboles a la herbivoría es un buen indicador de defensa vegetal y una estrategia efectiva de defensa de $C$. langsdorffii, además hay evidencia de respuesta trófica indirecta, como se postula en la segunda pregunta. En resumen, el patrón de fructificación supra-anual provoca varios efectos en el desarrollo de las plantas, mostrando la importancia de evaluar diversos rasgos vegetales al caracterizar la inversión de recursos de una especie. Como se esperaba, el cambio en la distribución de recursos modifica la producción de compuestos de defensa y los patrones de herbivoría. El entendimiento de este elemento importante de las interacciones insecto-planta será fundamental para 
descifrar la historia natural coevolutiva y las interacciones entre reproducción vegetal y ataque herbívoro. Además de eso, solo a través de estudios a largo plazo vamos a ser capaces de construir modelos y desarrollar pronósticos más precisos acerca de los factores que desencadenan el efecto de abajo hacia arriba en el rendimiento de la herbivoría, así el efecto de arriba hacia abajo de los herbívoros sobre la evolución de las plantas.

Palabras clave: defensas de plantas, distribución de recursos (trade-off) en plantas, fenología, fructificación masiva, insectos formadores de agallas.

\section{REFERENCES}

Abrahamson, W. G., \& Caswell, H. (1982). On the comparative allocation of biomass, energy, and nutrients in plants. Ecology, 63, 982-991.

Baldwin, I. T., Gorham, D., Schmelz, E. A., Lewandowski, C. A., \& Lynds, G. Y. (1998). Allocation of nitrogen to an inducible defense and seed production in Nicotiana attenuata. Oecologia, 115, 541-552.

Barbosa, M., \& Fernandes, G. W. (2014). Bottom-up effects on gall distribution. En G. W. Fernandes \& J. C. Santos (Eds.), Neotropical Insect Galls (pp. 99-113). New York: Springer.

Bazzaz, F. A., Chiariello, N. R., Coley, P. D., \& Pitelka L. F. (1987). Allocating resources to reproduction and defense. BioScience, 37, 58-67.

Bryant, J. P., Chapin, F. S., \& Klein, D. R. (1983). Carbon/ Nutrient Balance of Boreal Plants in Relation to Vertebrate Herbivory. Oikos, 40, 357-368.

Buckley, N. E., \& Sakar, G. A. (2013). Reproduction, growth, and defense trade-offs vary with gender and reproductive allocation in Ilex glabra (Aquifoliaceae). American Journal of Botany, 100, 357-364.

Coley, P. D. (1986). Costs and benefits of defense by tannins in a neotropical tree. Oecologia, 70, 238-241.

Coley, P. D., \& Barone, J. A. (1996). Herbivory and plant defenses in tropical forests. Annual Review of Ecology, Evolution, and Systematics, 27, 305-335.

Costa, F. V., Fagundes, M. F., \& Neves, F. S. (2010). Arquitetura da planta e diversidade de galhas associadas à Copaifera langsdorffii (Fabaceae). Ecología Austral, 20, 9-17.

Crawley, M. J. (2007). The R Book. Londres: John Wiley $\&$ Sons.

Dias, H. C. T., \& Oliveira-Filho, A. T. (1996). Fenologia de quatro espécies arbóreas de uma floresta estacional semidecídua em Lavras, MG. Cerne, 2, 66-88.
Dyer, L. A., Letourneau, D. K., Dodson, C. D., Tobler, M. A., Stireman III, J. O., \& Hsu, A. (2004). Ecological Causes and Consequences of Variation in Defensive Chemistry of a Neotropical Shrub. Ecology, 85, 2795-2803.

Espírito-Santo, M. M., Neves, F. S., Andrade-Neto, F. R., \& Fernandes, G. W. (2007). Plant architecture and meristem dynamics as the mechanisms determining the diversity of gall-inducing insects. Oecologia, 153, 353-364.

Fagundes, M., Maia, M. L. B., Queiroz, A. C. M., Fernandes, G. W., \& Costa, F. V. (2013a). Seed predation of Copaifera langsdorffii Desf. (Fabaceae: Caesalpinioideae) by Rhinochenus brevicollis Chevrolat (Coleoptera: Curculionidae) in a Cerrado fragment. Ecología Austral, 23, 218-221.

Fagundes, M., Costa, F. V., Antunes, S. F., Maia, M. L. B., Queiroz, A. C. M., Oliveira, L. Q., \& Faria, M. L. (2013b). The role of historical and ecological factors on initial survival of Copaifera langsdorffii Desf. (Fabaceae). Acta Botanica Brasilica, 27, 480-487.

Faria, M., \& Fernandes, G. W. (2001). Vigour of a dioecious shrub and attack by a galling herbivore. Ecological Entomology, 26, 37-45.

Feeny, P. (1976). Plant apparency and chemical defense. Recent Advances in Phytochemistry, 10, 1-40.

Fernandes, G. W. (1990). Hypersensitivity: a neglected plant resistance mechanism against insect herbivores. Environmental Entomology, 19, 1173-1182.

Fernandes, G. W., \& Negreiros, D. (2001). The occurrence and effectiveness of hypersensitive reaction against galling herbivores across host taxa. Ecological Entomology, 26, 46-55.

Fernandes, G. W., \& Price, P. W. (1992). The adaptative significance of insect gall distribution: survivorship of species in xeric and mesic habitat. Oecologia, 90, 14-20.

Fernandes, G. W., Santos, J. C., \& Gomes, V. M. (2012). Misleading herbivory in a tropical tree. AnthropodPlant Interactions, 6, 649-654.

Fowler, H. G., \& Duarte, L. C. (1991). Herbivore pressure in a Brazilian Cerrado. Naturalia, 16, 99-102.

Freitas, C. V., \& Oliveira, P. E. (2002). Biologia reprodutiva de Copaifera langsdorffii Desf. (Leguminosae, Caesalpinioideae). Brazilian Journal of Botany, 25, 311-321.

Hagerman, A. E. (1987). Radial diffusion method for determining tannin in plant extracts. Journal of Chemical Ecology, 13, 437-449.

Haring, D. A., Huber, M. J., Suter, D., Edwards, P. J., \& Scher, A. L. U. (2008). Plant enemy-derived 
elicitors increase the foliar tannin concentration of Onobrychis viciifolia without a trade-off to growth. Annals of Botany, 102, 979-987.

Hartley, S. E. (1998). The chemical composition of plant galls: are levels of nutrients and secondary compounds controlled by the gall-former? Oecologia, $113,492-501$

Haslam, E. (1988). Plant polyphenols (syn. vegetable tannins) and chemical defense - a reappraisal. Journal of Chemical Ecology, 14, 1789-1806.

Herms, D. A., \& Mattson, W. J. (1992). The dilemma of the plants: To grow or to defend. The Quarterly Review of Biology, 67, 283-335.

Hess, M. D., Abrahamson, W. G., \& Brown, J. M. (1996). Intraspecific Competition in the Goldenrod BallGallmaker (Eurosta solidaginis): Larval Mortality, Adult Fitness, Ovipositional and Host-Plant Response. The American Naturalist, 136, 121-133.

Imaji, A., \& Seiwa, K. (2010). Carbon allocation to defense, storage, and growth in seedlings of two temperate broad-leaved tree species. Oecologia, 162, 273-281.

Isagi, Y., Sugimura, K., Sumida, A., \& Ito, H. (1997). How does masting happen and synchronize? Journal of Theoretical Biology, 187, 231-239.

Ishihara, M. I., \& Kikuzawa, K. (2009). Annual and spatial variation in shoot demography associated with masting in Betula grossa: comparison between mature trees and saplings. Annals of Botany, 104, 1195-1205.

Janzen, D. H. (1971). Seed predation by animals. Annual Review of Ecology, Evolution, and Systematics, 2, 465-492.

Jing, S. W., \& Coley, P. D. (1990). Dioecy and herbivory: the effect of growth rate on plant defense in Acer negundo. Oikos, 58, 369-377.

Kelly, D. (1994). The evolutionary ecology of mast seeding. Trends in Ecology and Evolution, 9, 465-470.

Kelly, D., \& Sork, V. L. (2002). Mast seeding in perennial plants: why, how, where? Annual Review of Ecology, Evolution, and Systematics, 33, 427-447.

Larcher, W. (1995). Physiological Plant Ecology. Berlin: Springer Verlag.

Leite, A. M. C., \& Salomão, N. A. (1992). Estrutura populacional de regenerantes de copaíba (Copaifera langsdorffii Desf.) em mata ciliar do Distrito Federal. Acta Botanica Brasilica, 6, 123-134.

Marquis, R. J., Diniz, I. R., \& Morais, H. C. (2001). Patterns and correlates of interspecific variation in foliar insect herbivory and pathogen attack in Brazilian Cerrado. Journal of Tropical Ecology, 17, 127-148.
Mole, S. (1994). Trade-Offs and Constraints in Plant-Herbivore Defense Theory: A Life-History Perspective. Oikos, 71, 3-12.

Monks, A., \& Kelly, D. (2006). Testing the resource-matching hypothesis in the mast seeding tree Nothofagus truncata (Fagaceae). Austral Ecology, 31, 366-375.

Neves, F. S., Araújo, L. S., Fagundes, M., Espírito-Santo, M. M., Fernandes, G. W., Sánchez-Azofeifa, G. A., \& Quesada, M. (2010). Canopy herbivory and insect herbivore diversity in a dry forest-savana transition in Brazil. Biotropica, 42, 112-118.

Newstrom, L. E., Frankie, G. W., \& Baker, H. G. (1994). A New classification for plant phenology based on flowering patterns in lowland tropical rain forest trees at La Selva, Costa Rica. Biotropica, 26, 141-159.

Norton, D. A., \& Kelly, D. (1988). Mast seeding over 33 years by Dacrydium cupressinum Lamb. (rimu) (Podocarpaceae) in New Zealand: the importance of economies of scale. Functional Ecology, 2, 399-408.

Obeso, J. R. (2002). The costs of reproduction in plants. New Phytologist, 155, 321-348.

Pedroni, F., Sanchez, M., \& Santos, A. M. (2002). Fenologia da copaíba (Copaifera langsdorffii Desf. Leguminosae, Caesalpinioideae) em uma floresta semidecídua no sudeste do Brasil. Revista Brasileira de Botânica, 25, 183-194.

R Development Core Team (2008). R: A language and environment for statistical computing. Vienna: $\mathrm{R}$ Foundation for Statistical Computing.

Rasband, W. S. (1997-2014). Image J. U. S. National Institutes of Health, Bethesda, Maryland, USA. Available at: http://imagej.nih.gov/ij/

Ribeiro, S. P., Braga, O. A., Silva, C. H. L., \& Fernandes, G. W. (1999). Leaf polyphenols in brazilian melastomataceae: sclerophylly, habitats, and insect herbivores. Ecotropica, 5, 137-146.

Rizzini, C. T. (1997). Tratado de Fitogeografia do Brasil: Aspectos Ecológicos, Sociológicos e Florísticos. Rio de Janeiro: Âmbito Cultural.

Roslin, T., \& Salminen, J. P. (2008). Specialization pays off: contrasting effects of two types of tannins on oak specialist and generalist moth species. Oikos, 117, 1560-1568.

Sandvik, S. M., \& Eide, W. (2009). Costs of reproduction in circumpolar Parnassia palustris in light of global warming. Plant Ecology, 205, 1-11.

Satake, A., \& Iwasa Y. (2000). Pollen coupling of forest trees: forming synchronized and periodic reproduction out of chaos. Journal of Theoretical Biology, $203,63-84$. 
Sebbenn, A. M., Carvalho, A. C. M., Freitas, M. L. M., Moraes, S. M. B., Gaino, A. P. S. C., da Silva, J. M., Jolivet, C., \& Moraes, M. L. T. (2011). Low levels of realized seed and pollen gene flow and strong spatial genetic structure in a small, isolated and fragmented population of the tropical tree Copaifera langsdorffii Desf. Heredity, 106, 134-145.

Silva, J. O., Jesus, F. M., Fagundes, M., \& Fernandes, G. W. (2009). Esclerofilia, taninos e insetos herbívoros associados a Copaifera langsdorffii Desf. (Fabaceae: Caesalpinioideae) em área de transição Cerrado Caatinga no Brasil. Ecología Austral, 19, 197-206.

Souza, M. L., Solar R. R., \& Fagundes M. (2015). Reproductive strategy of Copaifera langsdorffii (Fabaceae): more seeds or better seeds? Revista de Biología Tropical, 63. 1161-1167.
Stamp, S. (2003). Out of the Quagmire of Plant Defense Hypotheses. The Quarterly Review of Biology, 78, 23-55.

Stone, G. N., \& Schönrogge, K. (2003). The adaptive significance of insect gall morphology. Trends in Ecology and Evolution, 18, 512-522.

Weiner, J., Campbell, L. G., Pino, J., \& Echarte, L. (2009). The allometry of reproduction within plant populations. Journal of Ecology, 97, 1220-1233.

Westphal, E., Bronner, R., \& Le Ret, M. (1981). Changes in leaves of susceptible and resistant Solanum dulcamara infested by the gall mite Eriophyes cladophthirus (Acarina, Eriphyoidea). Canadian Journal of Botany, 59, 875-882. 